\title{
Nocardiosis - an emerging complication in the clinical management of HIV infected patients
}

\author{
Chioma Onyinye Nwuba*, Gabriel Kogo, Ngozi Ogbu, Oluwafemi Abolarin, Robert Okonkwo \\ From 17th International Symposium on HIV and Emerging Infectious Diseases (ISHEID) \\ Marseille, France. 23-25 May 2012
}

\section{Introduction}

In Nigeria as well as other parts of Africa, little is known regarding the prevalence of nocardiosis among HIV positive patients. Nocardiosis is usually not considered in the differential diagnosis for tuberculosis (TB) since it is not regarded as an AIDS defining illness.

The aim of this study is to determine the prevalence of nocardiosis in HIV positive patients suspected of having tuberculosis.

\section{Materials and methods}

In this prospective study, sputum samples of $234 \mathrm{HIV}$ positive patients with suspected cases of pulmonary tuberculosis were analyzed for Mycobacterium TB and Nocardia specie. Each sample was processed by conventional Ziehl Neelsen stain and examined for the presence of acid fast bacilli (AFB). AFB negative samples were streaked on slopes of Sabouraud's dextrose agar and paraffin coated glass rods which acted as bait for Nocardia was introduced into each of these inoculated media and incubated at $37^{\circ} \mathrm{C}$. Cultures were examined after two weeks for the presence of cream/orange tufts around the rods suggestive of nocardia. The isolates were scraped and further identified using biochemical tests. The CD4 cell count of each patient was estimated using Becton Dickenson FACS count system.

\section{Results}

Of the 234 patient samples examined, 8 had positive culture for Nocardia. The prevalence of TB was 10.3\% while that of Nocardia spp was $3.4 \%$. All cases of nocardiosis detected was found in patients with CD4 count of $<200$ cells/ul with $75 \%$ of these cases having CD4 count below 100cells/ul.

\footnotetext{
* Correspondence: chioman4u@yahoo.com Pro-Act, Msh, llorin, Nigeria
}

(c) 2012 Nwuba et al; licensee BioMed Central Ltd. This is an Open Access article distributed under the terms of the Creative Commons Attribution License (http://creativecommons.org/licenses/by/2.0), which permits unrestricted use, distribution, and reproduction in any medium, provided the original work is properly cited.
Out of the 8 patients diagnosed with nocardiosis in this study, 7 (7.4\%) were not receiving antiretroviral therapy (ART) while $1(0.7 \%)$ with a CD4 count of 109 cells/ul had already commenced ART. We also observed that all 8 patients diagnosed with nocardiosis all had a negative AFB result after producing three sputum samples for TB analysis.

\section{Conclusions}

In Nigeria where HIV-related tuberculosis occurs frequently, some patients diagnosed as having sputum smear-negative pulmonary tuberculosis actually have nocardiosis. It is pertinent that TB laboratories include gram staining during routine investigations of sputum samples especially for patients who present with typical features of active tuberculosis but whose smears are repeatedly negative for AFB.

Published: 25 May 2012

doi:10.1186/1742-4690-9-S1-P134

Cite this article as: Nwuba et al: Nocardiosis - an emerging

complication in the clinical management of HIV infected patients.

Retrovirology 2012 9(Suppl 1):P134.

Submit your next manuscript to BioMed Central and take full advantage of:

- Convenient online submission

- Thorough peer review

- No space constraints or color figure charges

- Immediate publication on acceptance

- Inclusion in PubMed, CAS, Scopus and Google Scholar

- Research which is freely available for redistribution 